\title{
Did the Indian capital controls work as a tool of macroeconomic policy?
}

\author{
Ila Patnaik* Ajay Shah
}

July 11, 2012

\begin{abstract}
The present debate on capital controls emphasises their potential role as tools for macroeconomic and financial stability. The effectiveness of these tools may depend on whether a country has the legal and administrative machinery to implement capital controls. We contribute to the analysis of the costs and benefits of capital controls by studying the experience of India, a country that has a system of capital controls that had never been dismantled. We find that when used as tools of macroeconomic policy, during a capital surge, the Indian experience appears to be similar to that of other countries.
\end{abstract}

JEL Codes: F32, F33

Keywords: Capital controls, exchange rate regime, monetary policy, impossible trinity; financial stability.

*This paper draws on many useful discussions with Josh Felman. It has greatly benefited from the numerous improvements suggested in seminars at the IMF, ICRIER, NIPFP, and IGC. We acknowledge useful discussions with Stijn Claessens, Ayhan Kose, Prakash Loungani, Rex Ghosh, Jonathan Ostry, Sebastian Mallaby, Michael Carson, Michael Hutchison, Kalpana Kochhar, Sanjaya Panth, Olivier Blanchard, U. K. Sinha and K. P. Krishnan. We are grateful to the referees and editors for extensive feedback which helped to strengthen the paper substantially. 


\section{Introduction}

Financial integration can reduce the cost of capital, support capital deepening through higher investment, foster the diversification of investment risk and contribute to the development of financial markets. At the same time, for emerging economies, financial integration can create macroeconomic vulnerability with episodes of capital surge and reversals. A surge of capital inflows can lead to an appreciation of the exchange rate, which can adversely affect the tradeables sector. Attempts to prevent nominal currency appreciation during the surge can lead to a loss of monetary policy autonomy. High inflows of capital can cause credit booms and asset price bubbles. In the aftermath of a surge, a country may witness sudden reversals that create financial instability (Ostry et al., 2010).

Capital surges and reversals can potentially be restricted by capital controls. However, maintaining a system of capital controls imposes costs on the economy. Lower financial integration and price differences between foreign and domestic capital markets may be associated with a higher domestic cost of capital, with adverse implications for growth and welfare. In addition, the bureaucratic processes associated with capital controls can induce transactions costs and problems with governance.

The cross-country evidence in support of the benefits of financial integration is weak (Kose et al., 2010, 2009; Prasad and Rajan, 2008). At the same time, most emerging economies have chosen to dismantle the machinery of capital controls. Some of them have tried to navigate the trade-off by imposing transitory capital controls, when faced with a capital surge or flight.

However, the empirical literature on the effectiveness of capital controls for macroeconomic management finds that transitory capital controls have a relatively limited impact on the magnitude of flows (Ostry et al., 2010; Magud et al., 2011). While controls influence the composition of capital flows, they seem to do so only for a short time. Soon agents appear to find ways to circumvent controls on specific types of flows.

One reason for the relatively limited effectiveness of capital controls in the countries studied could be that these countries did not have the legal, institutional and administrative mechanisms for implementing comprehensive controls (Habermeier et al., 2011). Capital controls may be more effective in countries like India and China where controls are permanent, where the administrative machinery for imposing controls has not yet been dismantled. While India has liberalised its capital account, the legal and administrative framework for controls remains intact, so that when the government chooses, controls can be fully reimposed (Reddy, 1998). In addition to keeping the machinery in place so that controls could be tightened when required, policy makers in India have also sought to use controls to reduce financial fragility.

This motivates an analysis of these country experiences. Existing studies on India examine the effectiveness of controls, in so far as controls are able to drive a wedge between international and domestic markets, or, to impact the composition of capital inflows. They do not 
explicitly assess the effectiveness of capital control measures as a tool for macroeconomic policy.

Questions about the effectiveness of capital controls have gained increased importance in recent times. After the global financial crisis, the IMF has suggested that capital controls are a legitimate tool of macroeconomic policy, and may be imposed when a country is faced with a capital surge, and other tools such as exchange rate intervention and fiscal and monetary policy have failed (Ostry et al., 2011). In addition, macro-prudential regulatory policies could support controls as effective tools that can reduce credit growth, the buildup of asset bubbles, and lower risks associated with a surge (Ostry et al., 2012; Korinek, 2011).

When emerging economies witnessed a capital surge in the 2000s, India received amongst the highest capital inflows. In this episode, India tightened controls. These were mainly transitory price controls, easing of outflows, and some administrative measures. We compare the Indian experience on the effectiveness of capital controls as a tool for macroeconomic policy with that of other countries in this period.

It is possible that capital flows to India would have been even higher without the controls. In this paper, we do not try to assess the counter-factual. We limit ourselves to the question of whether the Indian experience differed from that of other countries on the same broad parameters. The contribution of this paper is to fill the gap that exists in the literature about the ways in which the existence of an administrative system of controls makes India's experience with capital controls, and their costs and benefits, different from that of countries that dismantled the regulatory framework for capital controls.

We find that in many ways the Indian experience during the surge did not differ from that of countries that opened their capital accounts, and imposed only transitory controls. Going by the measures of effectiveness of capital controls in the literature, it appears that capital control tightening measures could not adequately prevent the surge, a real exchange rate appreciation, provide complete monetary policy autonomy, or prevent a credit boom.

India's experience with financial stability concerns during the surge was somewhat mixed. In some respects, the outcomes seen in India were akin to those seen with more open countries, with the usual difficulties associated with a surge in capital inflows. While the combination of capital controls and macro-prudential measures does not appear to have been able to prevent high credit growth, it did restrict foreign currency debt flows to India. Maintaining the administrative machinery for capital controls seems to have placed a regulatory burden on the Indian financial system and raised concerns about rule of law.

The remainder of this paper is organised as follows. Section 2 summarises the institutional framework for capital controls in India. Section 3 describes the capital surge of the 2000s. Section 4 examines the extent to which the capital controls were able to deliver on reining in or averting the surge, improving autonomy of monetary policy, preventing real exchange rate appreciation and containing asset price booms. Section 5 focuses on debt inflows and problems of financial fragility. Section 6 turns to governance problems associated with the 
operations of capital controls in these years. Finally Section 7 concludes.

\section{Framework for capital controls}

Restrictions on cross-border transactions were first introduced in India as a wartime measure by the British in 1942. These grew into a complex framework of restrictions on the current and capital account, where violations were treated as a criminal offense. Following a structural adjustment program with the IMF in 1991, restrictions on the current account and the capital account began to be eased (Shah and Patnaik, 2011).

In 2000, the current account was made fully convertible, and a modified framework for capital controls was put in place. Under this framework, the goal of capital controls was to avoid a balance of payment crises. Private capital flows would finance the current account deficit, thus shifting away from the reliance on official debt and overseas aid (Reddy, 2000).

The need for capital inflows was coupled with concerns about the exchange rate regime. India had an administered fixed exchange rate until 1990, and was to evolve towards a 'market determined exchange rate'. Policy makers were, however, not comfortable with market determination of the exchange rate. Opening up the capital account could lead to either sharp inflows or outflows, which would change demand and supply conditions in the exchange rate market. This would make the rupee volatile, something that the policy makers wished to avoid (Reddy, 2004). Hence, while many controls were eased, the legal framework for reimposing controls was maintained to manage the exchange rate, by controlling the magnitude of capital flows when required (Reddy, 1998).

Every year, policy makers chose the 'optimal size' of the current account deficit. The Reserve Bank of India then tried to manage capital flows through various instruments available so as to ensure that capital flows were equal to the current account deficit. It was hoped that the small error, if any, would be absorbed in the change in reserves, thus giving a stable exchange rate (Reddy, 2000). The underlying belief was that with the large number of controls in the hands of the government, the magnitude of capital flows could be controlled.

\subsection{The regulatory framework}

Capital controls in India differ according to the type of investor, the markets operated in, and the assets bought or sold. The law has distinct rules for individual investors, foreign corporations and non-resident Indians differently from broad based funds, charitable trusts or university endowment funds (Sinha, 2010). Major elements of the system are:

Outward flows by individuals Individuals are limited to taking a specified amount of dollars per year out of the country. 
Outward flows by firms Outbound FDI by a firm is capped at a multiple of its net worth.

Foreign banks RBI restricts the growth of foreign banks by permitting all foreign banks, put together, to open 20 branches a year.

Foreign borrowing by firms Maturity of loan, amount, interest rate, end-use and the sector to which the debtor firm belongs, are prescribed. The aggregate borrowing by all firms in a year is subject to a ceiling.

Debt investment by foreign portfolio investors The aggregate investment by all foreign investors is subject to one ceiling for government bonds, and another for corporate bonds.

Equity investments by foreign portfolio investors Only registered "foreign institutional investors" are permitted to buy shares in India. Their investments are subject to sectoral and firm level ceilings.

FDI Foreign ownership in certain sectors (e.g. telecom, insurance, banking) is capped at various levels.

Many controls are quantitative in nature, alongside a few price-based restrictions, such as a ceiling on the interest rate for borrowing by banks from non-resident Indians. Similarly, the interest rate on borrowing by non-bank firms is capped. ${ }^{1}$

\subsection{India's capital account integration}

After 1991, quantitative restrictions on many cross-border flows have been eased over time. Capital inflows or outflows for sale or purchase of many kinds of assets, that were previously prohibited, have since been allowed. However, the system of restrictions has not been eliminated. Consequently, an index of capital account openness based on the 'Annual Report on Exchange Arrangements and Exchange Restrictions' of the IMF, such as Chinn and Ito (2008), which assesses merely the existence of restrictions in each broad category, shows that India's capital controls did not ease at all.

Measures of de jure openness suggest that India is more closed than other large emerging markets. Further, other emerging market economies have removed controls faster than India (Table 1). Detailed measures such as Abiad et al. (2010) and Quinn and Toyoda (2007) show some liberalisation. Abiad et al. (2010) show that restrictions on the capital account were eased between 1999 and 2004. Since then, the process of decontrol seems to have slowed down (Quinn and Toyoda, 2007). Schindler (2009), suggests that India eased capital controls for a short time but soon resumed higher restrictions. Indian capital controls have also been more restrictive on outward flows than on inward flows. In 2005,

\footnotetext{
${ }^{1}$ Other market based measures such as transaction taxes and reserve requirements were considered by policy makers, but considered inappropriate or cumbersome (Reddy, 1998).
} 
Table 1 Capital account openness of emerging markets

The table shows indices of capital account restrictions in six emerging markets. An increase in the reported score denotes de-control, except in the case of Schindler (2009), where increasing values imply increasing controls. This evidence suggests that India was a relatively closed economy when compared to peers.

\begin{tabular}{|c|c|c|c|c|c|c|c|c|}
\hline & \multicolumn{2}{|c|}{ Abiad } & \multicolumn{2}{|c|}{ Chinn-Ito } & \multicolumn{2}{|c|}{ Quinn } & \multicolumn{2}{|c|}{ Schindler } \\
\hline & 1991 & 2004 & 1991 & 2004 & 1991 & 2004 & 1995 & 2004 \\
\hline Brazil & 0.28 & 0.57 & -1.81 & 0.72 & 37.50 & 50.00 & 0.70 & 0.33 \\
\hline India & 0.09 & 0.61 & -1.18 & -1.18 & 37.50 & 50.00 & 1.00 & 0.95 \\
\hline Russia & . & 0.80 & .. & -0.09 & .. & 50.00 & 0.95 & 0.91 \\
\hline China & 0.08 & 0.48 & -1.13 & -1.13 & 18.75 & 25.00 & 1.00 & 1.00 \\
\hline South Africa & 0.53 & 0.86 & -1.81 & -1.13 & 37.50 & 50.00 & 0.65 & 0.67 \\
\hline Mexico & 0.71 & 0.95 & -0.09 & 1.18 & 62.50 & 62.50 & 1.00 & 0.37 \\
\hline
\end{tabular}

Figure 1 De facto financial integration

Lane and Milesi-Ferretti (2007) measure de facto financial integration as the stock of all external assets and liabilities of a country expressed as a ratio to GDP. India is less integrated than other emerging markets. It has also integrated more slowly.

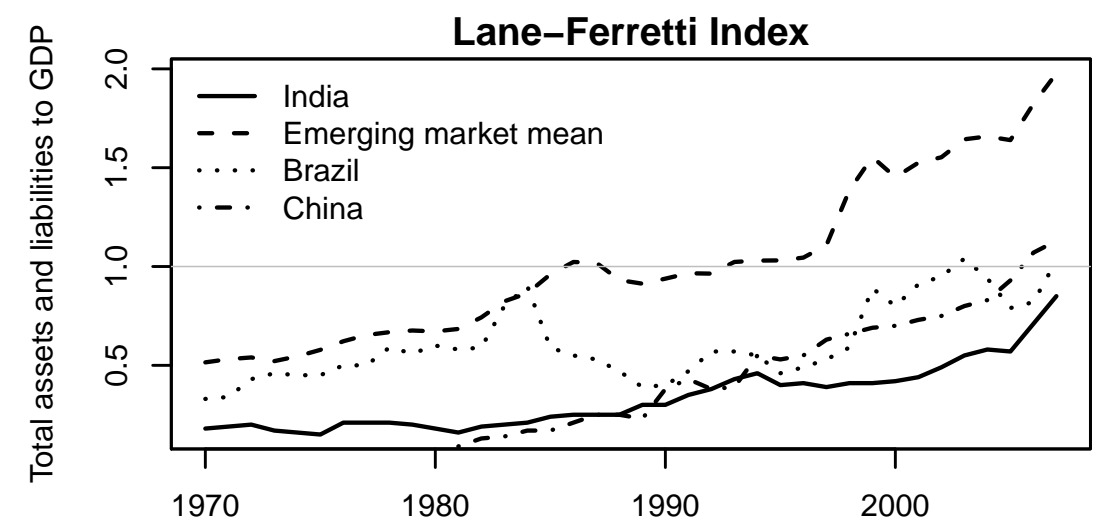

outward flows were highly restricted while inflow was restricted to a lesser extent (Schindler, 2009). Controls on outflows were eased after $2006 .^{2}$ Despite the easing, India did not eliminate restrictions on any category of cross-border flows.

Maintaining restrictions on capital flows reduced India's integration with the world. One measure of global financial integration is the stock of all external assets and liabilities of a country on the capital and financial account (Lane and Milesi-Ferretti, 2007). In 2007, India's rank was 148 out of the 179 countries by this measure of integration. It increased from $35 \%$ of GDP in 1991, to $44 \%$ in 2001 and $85 \%$ in 2007. However, Brazil and China rose from less than $50 \%$ in 1991 to more than $100 \%$ of their GDP by 2007 . The emerging market average in 2007 was roughly 2.3 times higher than the value for India.

\footnotetext{
${ }^{2}$ See Table 2 for details. Available de jure indices available for this period do not seem to measure these changes.
} 
The existence of the legal system of capital controls kept India more closed than most other emerging economies. This was not without costs. According to some government committee reports on the Indian financial sector, incomplete financial integration is identified as a factor inducing reduced liquidity and efficiency of financial markets, limited growth of the financial services industry and a higher cost of capital (Mistry, 2007; Rajan, 2008).

\section{$2.3 \quad$ Evidence of market distortions}

The law of one price holds in efficient markets. In the absence of restrictions on inflows and outflows of capital, price differentials of similar assets in different locations should vanish through arbitrage (Quinn et al., 2011). Capital controls can prevent arbitrage, and introduce a wedge between domestic and international markets.

The empirical evidence for India suggests deviations from no-arbitrage across the border in a number of ways. Hutchison et al. (2012); Ma et al. (2004) find deviations from covered interest parity. Shah and Patnaik (2007) find that these deviations have tended to persist over multi-month periods. Without capital controls, arbitrage would have wiped out such deviations almost instantly.

Similarly, Stigler et al. (2010) find persistent cross-market premiums on American Depository Receipts of Indian firms. If there are no restrictions on the trading of shares listed in foreign and domestic markets, the possibility of arbitrage would imply that the prices of the depositary receipt and the underlying share would be equal, after adjusting for exchange rate and transaction costs (Levy Yeyati et al., 2009; Edison and Warnock, 2008).

The existence of permanent capital controls appears to have effectively restricted arbitrage, and created wedges between prices at all times. Distortions in financial markets may be associated with costs for the economy. A government committee has suggested that the Indian bond, currency and derivatives markets has been hampered as a consequence of the system of capital controls (Mistry, 2007). ${ }^{3}$

\section{Imposing capital controls during a surge}

The elaborate system of capital controls did not rule out a capital surge, which came together in the 2000s. Capital flows to India increased steadily, from around USD 10 billion a year in the early 2000s, to USD 100 billion a year by early 2008 (Figure 2). Although the economy was growing rapidly during this period, inflows were rising even faster. In

\footnotetext{
${ }^{3}$ There are also concerns that the lack of development of a bond-currency-derivatives nexus has weakened monetary policy transmission in India (Mistry, 2007).
} 
Figure 2 The magnitude of capital inflows

India witnessed a capital surge in the 2000s. The graph shows the sum of capital inflows of the latest four quarters at each point in time. The figure on the left shows this in units of billion US dollars (with log scale), and the figure on the right as per cent to GDP. It also shows that capital inflows were not driven by the current account deficit.

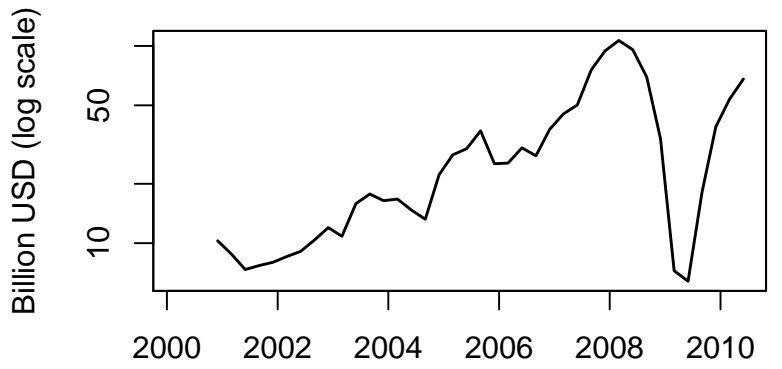

(a) Measured in USD

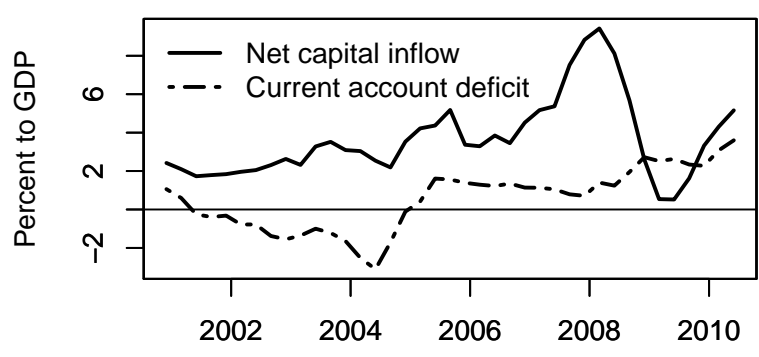

(b) Relative to GDP

the third quarter of 2007, at its peak, capital inflows were $13.6 \%$ of GDP. Various studies have identified these years as a period of a capital surge. ${ }^{4}$

A key challenge in opening up an economy is the conflict between a stable exchange rate, and monetary policy independence. While greater monetary independence could allow policy makers to stabilize the economy using monetary policy, greater exchange rate stability could result in higher international integration.

The movement towards one policy goal, such as higher financial integration, will either reduce exchange rate stability, or it may lower monetary independence, or some combination of the two. Many countries have occupied intermediate positions rather than the extreme corners of the trinity, when faced with this tradeoff. Emerging economies have moved more towards greater exchange rate flexibility, and hold much higher levels of international reserves as a buffer to handle shocks. In addition, emerging economies have also moved towards greater financial integration and lower monetary policy independence. In doing so, emerging economies have shown a preference for intermediate regimes (Aizenman et al., 2010).

In the context of these tradeoffs, and the sequencing of how to achieve their policy goals, Ostry et al. (2010) suggest that capital controls can be used as a measure of last resort. They propose that a country should respond to a temporary capital surge by letting the exchange rate appreciate, if it is not overvalued. If the exchange rate is overvalued, then it should buy dollars and build reserves, if it is desirable to do so. If the economy is overheating, it should sterilize its foreign exchange intervention. If the costs of sterilisation

\footnotetext{
${ }^{4}$ The Reserve Bank of India identified the period from 2001-02 as one marked with sustained surges in capital inflows (RBI, 2004). Pradhan et al. (2011) date the period of the surge as running from 1999 to 2008. Forbes and Warnock (2011), who study surges, stops, flight and retrenchment by defining sharp increases or decreases in inflows and outflows, rather than net capital inflows, identify the period of surge from October 2006 to March 2008.
} 
are too high, it should use fiscal policy to reduce capital surge. If reserves accumulation is not desirable, it should lower interest rates to reduce the surge. If the surge still continues, then as a last resort, it should impose capital controls, and combine them with macroprudential regulations.

Indian policy makers faced such questions after India started liberalizing its capital account. After India moved from a fixed exchange rate to a managed float, the Indian Rupee was de facto pegged to the US dollar (Patnaik, 2007). India thus faced the difficulties of any country trying to navigate the trilemma. With a pegged exchange rate, there would be a loss of monetary policy autonomy, unless capital controls were effective.

As both India and the world economy recovered after the Asian crisis, capital inflows to emerging economies, including India, rose. India's first policy response was to intervene in the foreign exchange market to prevent currency appreciation. Between 2001 to 2004, reserves doubled. Fiscal policy was also tightened as the fiscal deficit was reduced from 6.2 per cent of GDP in 2000-01 to 3.9 per cent of GDP in 2004-05. To avoid the inflationary impact of its intervention, the Reserve Bank of India sterilized the intervention. This became difficult when the Reserve Bank of India ran out of its stock of government bonds in 2004. Subsequently, India issued special sterilization bonds. ${ }^{5}$ Once the cost of sterilised intervention came transparently on the budget, this appears to have restricted sterilisation. Inflationary pressures seemed to be growing, fueled by rising demand and higher liquidity resulting from intervention in the foreign exchange market, that could be sterilised only partially. There was a choice between not intervening, and letting the exchange rate appreciate, versus buying dollars to prevent appreciation, and inducing higher inflation (Patnaik, 2005; Patnaik and Shah, 2009a). If the capital controls framework delivered, it would have been possible to pursue both goals; i.e. to have a stable exchange rate and lower inflation.

After 2006, a number of capital controls measures were announced. India's responses were similar in some respects to those by other emerging economies (Cardarelli et al., 2010). Authorities justified these capital controls as being motivated by macroeconomic difficulties. ${ }^{6}$ Measures adopted by India included easing of outflows, and increasing restrictions on inflows. Market based measures included reducing interest rates that could be paid on foreign debt (Table 2).

By 2006, many indicators suggested the economy was overheating. Faced with higher inflation and high GDP growth, the RBI raised interest rates repeatedly despite the surge. The exchange rate regime shifted towards greater flexibility (Figure 3). Fiscal policy was also tightened as the fiscal deficit was reduced further to 2.5 per cent in 2007-08. ${ }^{7}$

\footnotetext{
${ }^{5}$ The law does not permit the Reserve Bank of India to issue bonds. From 2004 onwards, sterilisation was done through the sale of 'Market Stabilisation Scheme' bonds. The interest cost of these bonds was clearly placed upon the exchequer.

${ }^{6}$ For instance, Reddy (2006) says "Capital flows are managed from the viewpoint of avoiding adverse impact on primary liquidity growth and inflationary pressures."

${ }^{7}$ The 2007-08 official figures need to be adjusted upwards to reflect off balance sheet borrowing.
} 
Table 2 Capital control measures, 2006-07

Capital control changes during the capital inflow surge in India between 2006-08 shows that restrictions on inflows were tightened and those on outflows eased. Interest rate ceilings for foreign borrowing were reduced to discourage foreigners from lending to India both for non-resident Indians and external commercial borrowings (ECBs).

\section{Restricting inflows}

12 May, 2006 'Overseas Corporate Bodies' were de-recognized as investors and lenders.

31 Jan, 2007 The ceiling on interest rates on non-resident bank deposits were reduced.

24 Apr, 2007 Interest rates on floating rate and non-resident bank deposits were further reduced.

21 May, 2007 ECBs by real estate companies were banned.

21 May, 2007 Interest rate ceiling on ECB were reduced.

7 Aug, 2007 Companies borrowing more than $\$ 20$ million in ECB were stopped from remitting funds.

\section{Encouraging outflows}

4 Dec, 2006 Prepayment limit on ECB was enhanced to $\$ 300$ million.

30 Apr, 2007 Prepayment limit was enhanced further to $\$ 400$ million.

$30 \mathrm{Apr}, 2007$ Registered Indian venture capital funds were allowed to invest in equity and equity-linked instruments of offshore venture capital undertakings.

31 May, 2007 Mutual funds were permitted to invest in certain overseas instruments.

14 Jun, 2007 The limit for overseas investment by an Indian company was raised to $300 \%$ its net worth.

14 Jun, 2007 Portfolio investment limits of Indian firms in foreign companies was raised.

26 Sep, 2007 Portfolio investment limits of Indian firms in foreign companies was raised again.

26 Sep, 2007 Indian firms were permitted to invest in overseas joint venture or in wholly owned subsidiaries up to $400 \%$ of their net worth.

26 Sep, 2007 Aggregate ceiling for overseas investment by mutual funds was raised.

30 Oct, 2007 Aggregate ceiling for overseas investment by mutual funds was raised again.

\section{Figure 3 Rupee volatility}

This figure shows the time-series of moving window volatility of the rupee-dollar rate. Each point in the graph is the annualised volatility of two years of weekly percentage changes in the rupee, with a centred window. This shows two dates of structural change in the exchange rate regime, each of which was a near-doubling of exchange rate volatility (Zeileis et al., 2010; Patnaik et al., 2011). When the headroom for sterilised intervention was lost in 2003, the annualised volatility of the rupee-dollar rate rose from $2.31 \%$ per year to $3.93 \%$ per year. In March 2007, there was another sharp rise to $9.14 \%$ per year.

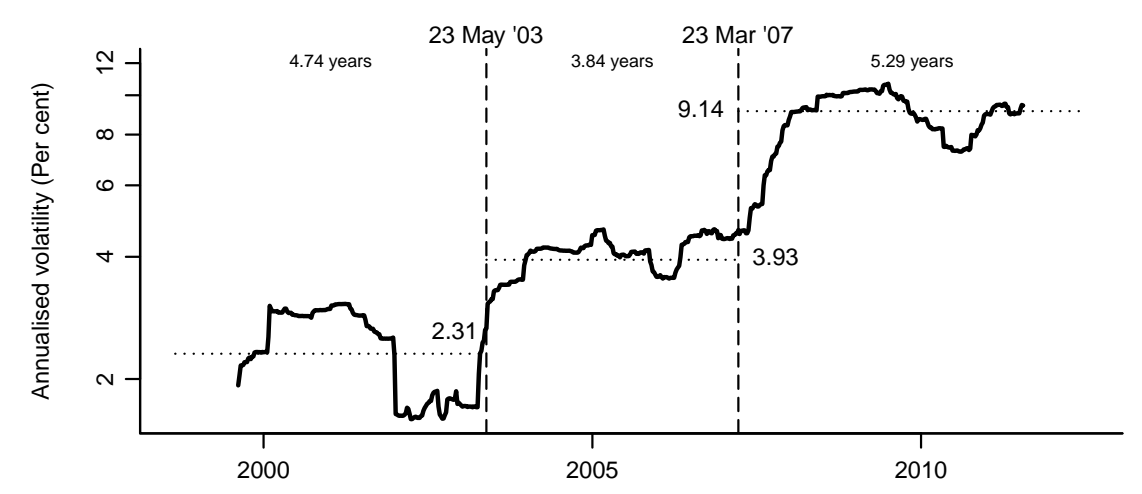




\section{Effectiveness of controls}

Cross-country evidence suggests that capital controls may have only a limited and short term impact on the composition of flows, and little impact on the overall volume of net flows. However, the empirical literature on the effectiveness of capital controls lacks a common methodology (Magud et al., 2011; Kokenyne and Baba, 2011; Binici et al., 2010; Habermeier et al., 2011). There are multiple definitions of what constitutes a success of capital controls. Authorities appear to portray their own actions as being motivated by lofty objectives. So while it is useful to study the official position, and compare the effectiveness of controls on the basis of the stated objectives, the research literature generally goes beyond stated objectives (Magud et al., 2011). Drawing on the empirical literature in the context of transitory controls, we examine the effectiveness of capital controls in four dimensions: (a) the magnitude of flows, (b) the real exchange rate, (c) monetary policy independence and (d) credit and asset price booms in India during the surge.

\subsection{Magnitude of flows}

Despite the measures announced to reduce the volume of capital inflows, India witnessed a capital surge which peaked in 2007-08, when capital flows rose to 8 percent of GDP. With net capital flows of US $\$ 98$ billion during 2007, India was the third largest recipient of net capital flows, after the United States and Spain, and the biggest recipient of capital flows amongst emerging markets.

The failure of capital controls in adequately controlling the volume of inflows in a surge is consistent with the evidence for other countries (Magud et al., 2011; Binici et al., 2010; Ostry et al., 2010). Controls appear to be more effective in dealing with temporary surges in capital flows (Kokenyne and Baba, 2011). Evidence suggests that when Japan introduced capital controls on deposits, it modestly reduced the volume of short-term capital flows. Based on this evidence, Esaka and Takagi (2012) conclude that that market-based controls must be nearly prohibitive, perhaps combined with administrative measures, to be effective in a meaningful way.

The Indian evidence suggests that the presence of the legal framework for long-term capital controls of a comprehensive nature do not appear to have been sufficient to prevent a surge. It is possible that without the controls the surge may have been bigger. However, it may also be true that the controls were known and understood by economic agents who had learnt how to navigate them (Prasad, 2009). 
Figure 4 Monetary policy autonomy

This figure presents a measure of monetary policy autonomy from Aizenman et al. (2010) where higher values indicate greater autonomy. It shows that India had the lowest monetary policy autonomy during the 2000s.

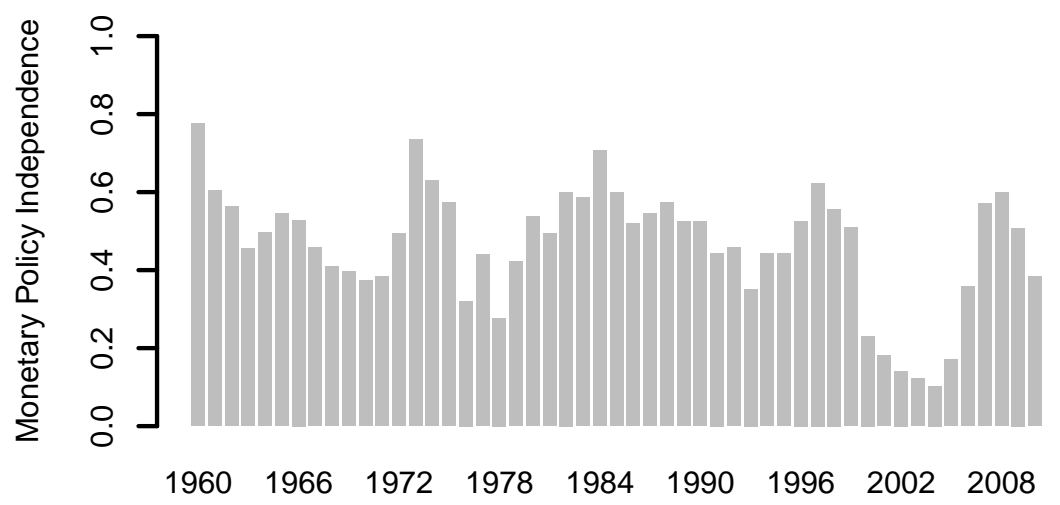

\subsection{Monetary policy autonomy}

A few researchers have tried to test whether capital controls have provided monetary policy independence, using alternative methodological approaches (Magud et al., 2011; Hutchison et al., 2012; Ostry et al., 2010; Kokenyne and Baba, 2011), with mixed results. The evidence for India suggests that while capital controls may have provided some monetary policy autonomy, it was incomplete.

Kohli (2012) found deviations from uncovered interest parity in India indicating that controls introduced a persistent wedge between foreign and domestic markets. This has been interpreted as capital controls providing India monetary policy autonomy. However, when facing policy choices posed by the "trilemma", a country may choose to intervene in foreign exchange markets for long periods of time, which may allow a wedge between foreign and domestic interest rates to persist. India intervened consistently from 2000 to 2007, and was thus able to achieve monetary policy autonomy by this measure.

On the other hand, Aizenman et al. (2011) measures monetary policy autonomy as the correlation of monthly interest rates between the home country and the base country. For India, their index shows that, when compared to the previous two decades, India's monetary policy independence was the lowest from 2000 to 2006. (Figure 4). This suggests some loss of monetary policy autonomy in this period.

During the capital surge in India, inflationary pressures started building up as India continued to intervene in the foreign exchange market. At the same time, the economy was showing many signs of overheating. ${ }^{8}$ Monetary policy choices were problematic. Partial

\footnotetext{
${ }^{8}$ See the cover story in The Economist of 3 February 2007 titled "India on fire" that focussed on India's overheating economy.
} 
Figure 5 Real effective exchange rate

This figure presents the time-series of the real effective exchange rate for India. It shows that the real effective exchange rate appreciated during the period of capital surge. The dashed lines identify two standard deviations about the long-term mean.

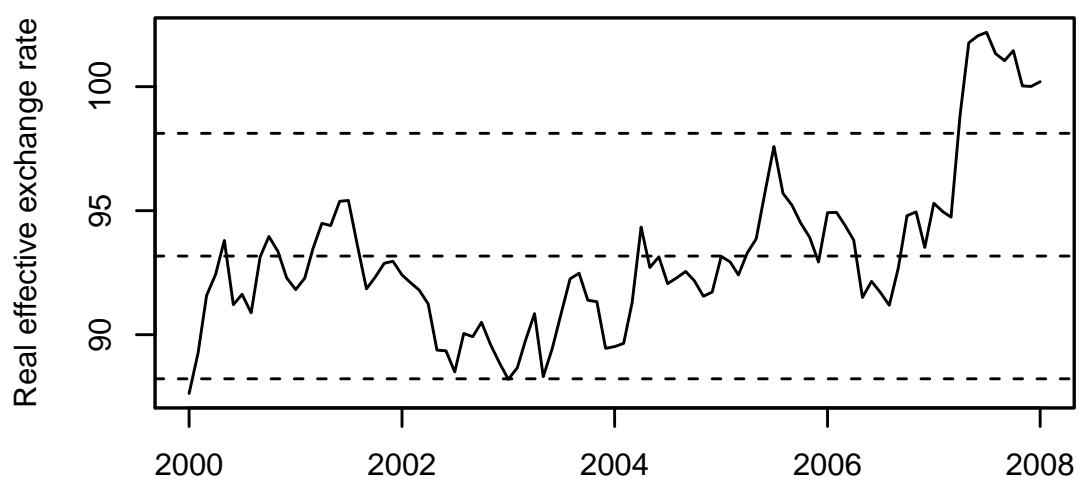

sterilisation of foreign exchange intervention was exerting downward pressure on interest rates, which ran contrary to the goal of controlling inflation. The exchange rate was appreciating, which ran contrary to the goal of holding down exchange rate flexibility and of using monetary policy to support the international competitiveness of the tradeables sector. The attempts to pursue both goals - to tighten monetary policy to stabilize output and inflation, and to keep low exchange rate volatility - did not seem to be entirely successful despite increasing restrictions on capital inflows and encouraging outflows. The policy rate was raised by the central bank many times, but the real rate fell from $+3 \%$ to $-4 \%$ during the surge (Patnaik and Shah, 2009a). Capital controls do not appear to have eliminated this policy contradiction.

In March 2007, India chose in favour of higher rupee volatility. This seems to have restored monetary policy autonomy according to the Aizenman et al. (2011) measure. This evidence suggests that capital controls were inadequate in providing complete monetary policy autonomy.

\subsection{Real exchange rate appreciation}

Another concern of policy makers in a capital surge is the possibility of a strong real exchange rate appreciation. The "trilemma" suggests that countries facing large capital inflows must make a choice between nominal appreciation and inflation. Countries have sometimes chosen a policy of sterilised intervention to reduce the conflict between these two objectives. But, in general, they were not able to prevent real exchange rate appreciation, either due to movements in the nominal rate, or in inflation. However, even if a country succeeds in maintaining a nominal peg, this may not prevent an appreciation of the real 
Table 3 Stock price booms (Jan - 2004 to Aug - 2008)

We identify the highest and the lowest value of the stock market index in the period from January 2004 to August 2008 for a group of emerging markets. This allows us to identify sharp asset price booms. The countries are sorted from left to right by the magnitude of the asset price boom. India was the 3rd biggest asset price boom, with stock prices at the peak which were 4.53 times higher than the level seen at the bottom.

\begin{tabular}{|c|c|c|c|c|c|c|c|c|c|c|}
\hline Country & Peru & China & India & Indonesia & Brazil & Russia & Turkey & Korea & Argentina & Philippines \\
\hline Rank & 1 & 2 & 3 & 4 & 5 & 6 & 7 & 8 & 9 & 10 \\
\hline Lowest & 2493.81 & 1011.50 & 1388.75 & 668.48 & 17604.00 & 6378.83 & 15922.44 & 719.59 & 839.93 & 1388.15 \\
\hline Highest & 23789.75 & 6092.06 & 6287.85 & 2830.26 & 73517 & 26196.44 & 58231.9 & 2064.85 & 2351.44 & 3873.5 \\
\hline Ratio & 9.54 & 6.02 & 4.53 & 4.23 & 4.18 & 4.11 & 3.66 & 2.87 & 2.80 & 2.79 \\
\hline
\end{tabular}

exchange rate when faced with large capital flows. This emphasises real exchange rate appreciation as a test of the effectiveness of capital controls (Warnock, 2011; Gregorio, 2011). Further, countries have witnessed real exchange rate appreciations, even when capital controls were introduced (Cardarelli et al., 2010). ${ }^{9}$

Aizenman et al. (2011) find that in trying to navigate the trilemma, countries faced with large capital flows tend to allow exchange rate flexibility. Maintaining he soft peg to the dollar was putting upward pressure on inflation due to partially sterilised intervention, hence India allowed greater exchange rate flexibility. At the same time, intervention continued. Inflation continued to rise, putting pressure on the real effective exchange rate (Patnaik and Shah, 2009a).

The real effective exchange rate for the rupee rose sharply during the surge (Figure 5). The Indian experience was thus similar to that of other, more open, countries that levied temporary controls during surges on capital flows and witnessed rapid appreciation of the real exchange rate (Inci et al., 2000).

\subsection{Asset prices}

Foreign capital surges may also be accompanied by a credit boom (Reinhart and Rogoff, 2009). During the surge, bank credit in India was growing at more than 30 per cent. This has been identified as one of the periods in which India faced a credit boom. ${ }^{10}$ There is now increasing interest in the case for prudential capital controls for managing macroeconomic and financial stability challenges during a capital surge (Ostry et al., 2012; Korinek, 2011; Habermeier et al., 2011). Alongside capital controls, India imposed counter-cyclical macro-prudential measures on the banking sector. ${ }^{11}$ Though credit growth still remained very high, evidence suggests that these measures appeared to have helped in reducing the

\footnotetext{
${ }^{9}$ Malaysia was an exception witnessing less rapid appreciation.

${ }^{10}$ See Table 1 in Elekdag and Wu (2011).

${ }^{11}$ See: Table 2.1, Financial Stability Report, Reserve Bank of India, (March 2010) for a description of counter-cyclical prudential regulation for banks.
} 
Figure 6 Composition of flows into India

This graph shows liabilities as percent of GDP. The share of foreign debt to total flows declined as India eased restrictions on other capital inflows while maintaining ceilings on debt flows.

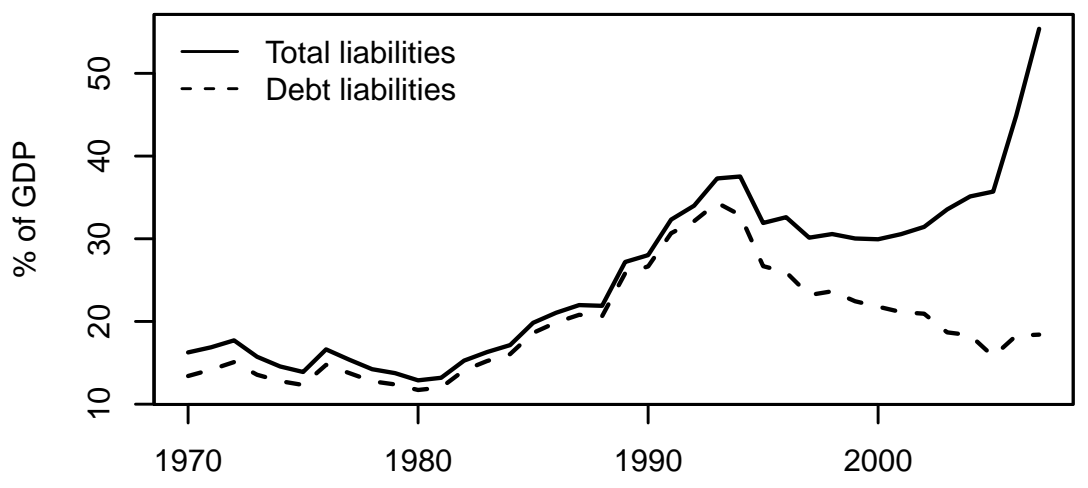

magnitude of sectoral credit, loans given by banks for housing. However, total credit, including non-bank credit, to the housing sector and house prices continued to grow (Patnaik and Shah, 2011).

Capital surge into emerging markets in the 2000s, appears to have been accompanied by stock market booms. These may be measured by the ratio of the highest value of the stock market index to the lowest value of the stock market index in the period of the surge. Among emerging market countries, India had one of the biggest asset price booms (Table 3). Emerging markets with high capital account openness, such as Chile, Israel and Korea, did not seem to witness higher asset price booms than relatively closed economies such as China and India.

\section{Impact of capital controls on debt inflows}

Even if there is no episode of surge or flight of capital, capital inflows can cause financial fragility in an emerging economy if the inflows are largely short term debt flows. Further, debt flows and their financing terms tend to be highly pro-cyclical (Kaminsky et al., 2005). Consequently, countries that rely to a great extent on foreign currency debt are doubly vulnerable as the much needed financing is not available when there is a negative shock. A shock to the exchange rate can lead to significant contractionary balance sheet effects. Capital account liberalization that allows agents to run currency mismatches can make the economy vulnerable. When the government suppresses the volatility of the exchange rate, this reduces the incentives of agents to hedge their currency exposure. In addition, incomplete financial markets in emerging economies may limit the capacity of the firms to hedge. 
The recent theoretical literature on capital controls suggests that one way to reduce balance sheet effects, and hence the contraction of the real economy when a surge ends, is by increasing private costs of foreign currency denominated debt (Korinek, 2011). Since dollar debt has low private costs and high social costs, taxes, or equivalent quantitative controls, may be used to increase the private cost of foreign borrowing. Recent research suggests that controls on the composition of capital, such as on debt, may reduce the vulnerability of a country to a crisis (Ostry et al., 2012).

The empirical literature on the effectiveness of capital controls suggests that while controls may not be very effective in reducing the magnitude of capital inflows, they may be able to influence the composition of flows (Magud et al., 2011; Ostry et al., 2010; Binici et al., 2010; Habermeier et al., 2011). The initial effectiveness of controls on the composition of flows tends to dissipate as agents find ways to circumvent these controls (Ostry et al., 2010).

Cross-country evidence seems to suggest that price-based controls on inflows were rarely effective in discouraging capital inflows, or altering their composition. For instance in Chile, Brazil, Columbia, Thailand and Korea, the impact of capital controls was found to be temporary. It is also seen that designing effective controls is more difficult in countries with more developed financial markets, because market participants can easily find a way to circumvent them (Edwards and Rigobon, 2009; Kokenyne and Baba, 2011).

\subsection{Controls on debt flows}

When India liberalised the capital account, policy makers were cautious about permitting foreign borrowing. Capital controls sought to shift the composition of capital flows away from debt to non-debt creating inflows and regulate external commercial borrowings, especially short term debt (Mohan and Kapur, 2009; Gopinath, 2011). ${ }^{12}$ As a consequence, while the framework for foreign investment, both for FDI, and for portfolio flows, is relatively liberal, India has an number of restrictions on debt. ${ }^{13}$ Short-term debt, including trade-related payments beyond 180 days, is subject to strict case-by-case approval of purpose, amount and terms. ${ }^{14}$ Offshore borrowing by firms or 'External Commercial Borrowings' (ECB) require permission from the central bank with rules for size, sector and end use. Over and above this, the magnitude of total debt inflows under ECB is controlled with an overall annual ceiling. On rupee denominated debt, quantitative limits exist on the total amount owned by all foreign investors in government and corporate bonds. Price based restrictions include ceilings on interest paid on ECBs or by banks to Non-Resident Indians

\footnotetext{
${ }^{12}$ The new policy framework was based on the recommendations of the High level committee report on Balance of Payments in 1999.

${ }^{13}$ FDI inflows rose from $0.5 \%$ of GDP in 2000 to $2.8 \%$ in 2010 , above the emerging market average, and second only to China.

${ }^{14}$ As a signatory to IMF's Article VIII India has to allow capital flows related to trade.
} 
and are changed regularly depending on whether capital inflows are to be encouraged or discouraged.

The empirical literature on capital inflows to India finds that controls appear to have impacted the composition of flows to India (Pradhan et al., 2011; Habermeier et al., 2011) (Figure 6). It is estimated that, a reduction of 100 basis points in interest rate ceilings on each of the bank deposit schemes for Non-Resident Indians is associated with a decline of over USD 400 million in these schemes (Mohan and Kapur, 2009).

\subsection{Balance sheet exposure of firms}

The Indian experience with restrictions on debt suggests that if controls are comprehensive and if the administrative framework for controls exists, then it may be possible to prevent firms from borrowing too much abroad. But capital controls on foreign borrowing are a means to an end. The objective is to increase the resilience of the economy by reducing unhedged currency exposure of firms. However, strict controls on foreign borrowing may not always yield this desired outcome. Lower currency volatility may encourage firms to take on unhedged currency exposure. This behaviour may be reinforced by incomplete markets for hedging (Schneider and Tornell, 2004; Chang and Velasco, 2006).

Evidence suggests that when exchange rate flexibility went down in India, unhedged currency exposure of Indian firms went up, and vice versa (Patnaik and Shah, 2010). Capital controls could thus restrict the amount of borrowing firms do, but could not incentivize them to hedge those risks. In periods of higher currency volatility, with similar capital controls on debt in place, firms chose to hedge their currency exposure. Thus, for reducing the vulnerability of firms, while there may be a role for capital controls, there may be equally important role for currency flexibility. Restrictions on debt flows may not be adequate. If they are accompanied by higher currency flexibility they may be more effective in achieving the goals of lower balance sheet mismatches and reduced financial fragility.

\subsection{Money market during the Lehman crisis}

Another element of evidence about capital controls is obtained in the days after the Lehman crisis. In September 2008, the prevailing capital controls regime in India prohibited shortterm debt flows. Considering capital controls on short term debt, domestic money markets should have been insulated from shocks in international money markets.

However, when the Lehman bankruptcy took place, the operating procedure of monetary policy came under stress, and the call money rate rose sharply, breaching the bounds demanded by the operating procedure of monetary policy. Immediately after the Lehman bankruptcy, the overnight money market rates rose to $17 \%$ (Aziz et al., 2008; Patnaik and Shah, 2009b). Onshore entities had much more exposure to the money market in London 
$\underline{\text { Figure } 7 \text { Stress in the operating procedure of monetary policy after Lehman bankruptcy }}$

The operating procedure of monetary policy involves keeping the market rate (the call money rate) between the 'repo rate' and the 'reverse repo rate'. When Lehman failed, the operating procedure of monetary policy broke down. This raises questions about the effectiveness of capital controls against short-dated borrowing.

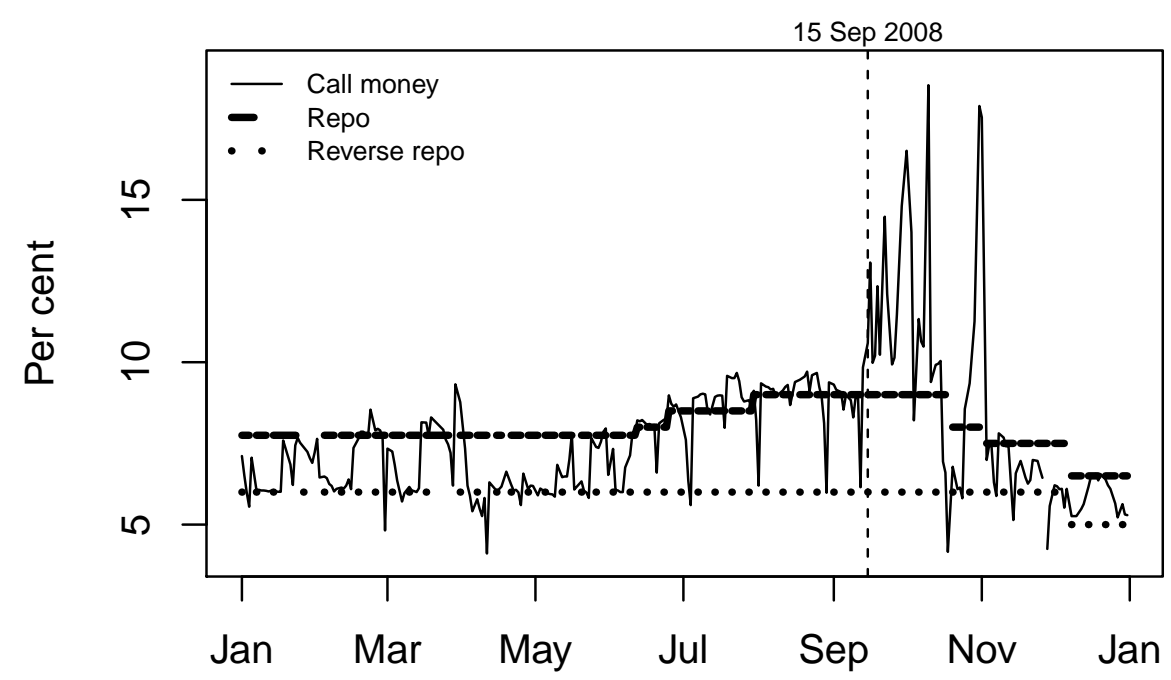

than was supposed to feasible under the capital controls; the onshore money market was much more integrated with the money market in London than was supposed to be under the capital controls. This episode raises questions about the effectiveness of capital controls on short-term debt.

\subsection{End-use restrictions}

Indian rules on foreign borrowing include 'end-use restrictions': rules that limit what can be done using money borrowed abroad. Such restrictions may have consequences beyond the objective of altering the composition of capital flows. As an example, on 7 August 2007, a fresh capital control was brought in against foreign currency borrowing: Foreign currency borrowing was restricted to be used for the purpose of importing capital goods.

The incentive implications of this rule change appears to have induced some unintended consequences. Reflecting the restrictions on the use of ECBs for rupee expenditure, the proportion of borrowings used for import of capital goods increased from around 25 per cent during 2005-06 and 2006-07 to 41 per cent during 2007-08 and the share of rupee expenditure fell from around 14 per cent to 3 per cent over the same period (Mohan and Kapur, 2009).

As shown in Figure 8, the capital control of 7 August 2007 was followed by a surge of 
Figure 8 Capital controls that encourage import of capital goods

On 7 August 2007, a fresh capital control was brought in against foreign currency borrowing. Foreign currency borrowing had to be used only for importing capital goods. As the graph shows, this gave a surge of imports of capital goods; domestic firms may have substituted away from domestic capital goods in order to obtain cheap credit. On 23 October 2008, when this end-use restriction was rescinded, imports of capital goods dropped sharply. The figure below presents the seasonally adjusted levels of capital goods imports and domestic capital goods production index (IIP), both indexed to Jan-2004 as 100 .

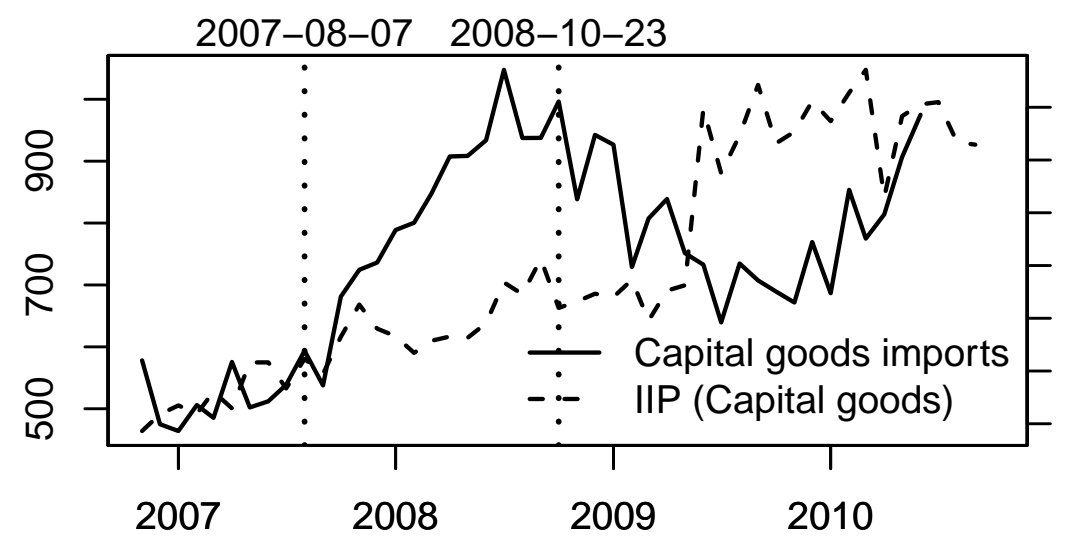

imports of capital goods. Domestic firms may have substituted away from domestic capital goods. On 23 October 2008, when this end-use restriction was rescinded, imports of capital goods dropped sharply. The lower line shows the time-series of domestic capital goods production, which rose again. ${ }^{15}$

\section{Governance dimensions of capital controls}

The salient elements of India's capital controls framework were the multiple instruments quantitative limits, price based measures as well as administrative measures for foreign currency borrowing by corporates (Gopinath, 2011). This framework was implemented through binding price controls that changed year by year, ceilings on the country's total foreign borrowing and case by case permissions. The implementation of this framework was crucially related to the framework for domestic financial regulation, where all instrument, transactions, agents and markets are prohibited, unless explicitly permitted. The capital controls framework seen in India is unlikely to work without a rules-based approach to financial regulation. The framework depended not only on the presence of the administrative machinery for controls, but also gave discretionary powers to the government.

During the surge, various elements of the capital controls system, and of the financial

\footnotetext{
${ }^{15}$ We estimated an ARIMA model of the seasonally adjusted growth rate of capital goods imports along with a dummy for the period during which the rupee-related restrictions were in place, after controlling for the world price of capital goods. The coefficient on the dummy variable is significant and positive.
} 
regulatory system, were used to cope with the surge. While some of these levers were constructed as part of capital controls, other instruments brought into play were those which had not been designed as legitimate instruments of capital control. A government committee that reviewed the framework of controls from the point of view of sound governance, found that many of the controls imposed during the surge violated principles of rule of law (Sinha, 2010):

Hindering venture capital An attempt was made to prevent inflows by venture capital funds. As a first step, tax pass-through to avoid double taxation for all venture capital was restricted to nine sectors: poultry, dairy, nanotechnology, biofuels, hotels and hospitality, seed research, etc. This rule change impacted not just foreign venture capital funds, but domestic venture capital funds also. Even if a foreign investor was willing to be double-taxed, they had difficulties opening a bank account. Venture capital investment into India requires a registration by the venture capital fund at the RBI, and RBI made such registration conditional upon investment by the venture capital fund in only these nine sectors. RBI also restricted venture capital inflows through their control over the ability of the foreign investors to open bank accounts in India. Permissions granted by the Reserve Bank of India appear to have been tied to requirements such as investment in only the nine sectors mentioned for taxpass through treatment in the Income Tax Act. This happened even though capital control laws did not explicitly provide for either registration or bank accounts being linked to the nine sectors (Sinha, 2010).

SEBI registration In the peak of the surge, the Securities and Exchange Board of India did not register investment managers as Foreign Institutional Investors even if they otherwise met rules for registration, if the investment manager was owned or substantially owned by Non Resident Indians. Capital control laws did not explicitly provide for this restriction (Sinha, 2010).

Automatic route In certain situations, India had placed foreign investment and foreign borrowing by Indian companies under the External Commercial Borrowing rules on an "automatic route", where Reserve Bank of India would automatically approve inflows that met the stated criteria. ${ }^{16}$ But meetings needed to be held by the Reserve Bank of India to approve the same. Capital inflows were prevented by not holding these meetings for many months during the surge. This was seen as constituting a violation of the principles of rule of law (Sinha, 2010).

Restrictions on offshore derivatives The term 'participatory notes' refers to the market for over-the-counter derivatives on Indian shares that trades offshore. The participants on this market are registered Foreign Institutional Investors in India, and

\footnotetext{
${ }^{16}$ External borrowing by firms must be of at least 3 years maturity below a specified sum and of at least 5 years maturity beyond. Borrowing up to a specified sum by a firm "for certain specified end-users" - e.g. expanding a factory, or importing capital goods - is allowed without requiring permissions. This is subject to a ceiling whereby approvals for borrowing by all firms (put together), in a year, should not exceed a given limit per year.
} 
they lay off the risk of their overall book using transactions on the onshore market. These overseas transactions are outside the jurisdiction of the Indian authorities. In October 2007, the Indian authorities tried to restrict registered FIIs from their transactions overseas on this market, in an attempt to reduce capital inflows. This was seen as going beyond their regulatory powers (Sinha, 2010).

\section{Conclusion}

The focus of the current debate on capital controls is the role of capital controls as a tool for macroeconomic and financial stability. Empirical support for the effectiveness of capital controls as a tool for macroeconomic policy is limited. India's experience, reviewed in this paper, does not appear to offer evidence to support the view that capital controls may be an effective tool for macroeconomic policy when a country does not dismantle its long run legal and administrative machinery for controls.

As a tool for increasing financial stability, the evidence from India suggests that capital controls can achieve lower debt flows when prohibitory price, quantitative and administrative controls are imposed in the framework of a financial regulatory regime where all financial transactions are illegal unless explicitly permitted. There appears to exist a trade-off between lower unhedged foreign currency borrowing by households and firms, and a lower regulatory burden on financial markets, both of which are desirable. The regulatory burden associated with capital controls seems to have raised concerns among policy makers in India; this paper brings out links between the problems of governance and the effective operation of a large administrative machinery of capital controls. The official thinking in India appears to be in favour of improving governance, lowering the regulatory burden, and reducing capital controls. ${ }^{17}$

The Indian experience also emphasises the role of currency flexibility, as a tool for reducing balance sheet mismatches. Theoretical work on balance sheet effects, such as Korinek (2011) needs to incorporate this element in the analysis. The literature has emphasised that the costs of capital controls should be assessed before blessing capital controls as legitimate instruments (Warnock, 2011; Habermeier et al., 2011). Our study supports this conclusion in the context of a country that maintained the framework of law, administration and regulation to impose capital controls.

\footnotetext{
${ }^{17}$ Government committee reports on making Mumbai an international financial centre, on domestic financial sector reform, and on rationalising capital controls have recommended dismantling many capital controls. Currently, a financial sector legislative reforms commission is reviewing and redrafting all financial law, including the capital controls law.
} 


\section{References}

Abiad, A., E. Detragiache, and T. Tressel (2010). A new database of financial reforms. IMF Staff Papers 57(2), 281-302.

Aizenman, J., M. Chinn, and H. Ito (2011). Surfing the waves of globalization: Asia and financial globalization in the context of the trilemma. Journal of the Japanese and International Economics 25, 290-320.

Aizenman, J., M. D. Chinn, and H. Ito (2010). The emerging global financial architecture: Tracing and evaluating new patterns of the trilemma configuration. Journal of International Money and Finance 29(4), 615-641.

Aziz, J., I. Patnaik, and A. Shah (2008). The current liquidity crunch in India: Diagnosis and policy response. Unpublished manuscript, National Institute of Public Finance and Policy.

Binici, M., M. Hutchison, and M. Schindler (2010). Controlling capital? legal restrictions and the asset composition of international financial flows. Journal of International Money and Finance 29(4), 666-684.

Cardarelli, R., S. Elekdag, and M. A. Kose (2010). Capital inflows: Macroeconomic implications and policy responses. Economic Systems 34(4), 333-356.

Chang, R. and A. Velasco (2006). Currency mismatches and monetary policy: A tale of two equilibria. Journal of International Economics 69(1), 150-175.

Chinn, M. and H. Ito (2008). A new measure of financial openness. Journal of Comparative Policy Analysis 10(3), 309-322.

Edison, H. and F. Warnock (2008). Cross-border listings, capital controls, and equity flows to emerging markets. Journal of International Money and Finance 27(6), 1013-1027.

Edwards, S. and R. Rigobon (2009). Capital controls on inflows, exchange rate volatility and external vulnerability. Journal of International Economics 78(2), 256-267.

Elekdag, S. and Y. Wu (2011). Rapid credit growth: Boon or boom-bust? Working Paper 11/241, International Monetary Fund.

Esaka, T. and S. Takagi (2012). Testing the Effectiveness of Market-Based Controls: Evidence from the Experience of Japan with Short-Term Capital Flows in the 1970s. Working Paper 12-03, Osaka University.

Forbes, K. J. and F. E. Warnock (2011). Capital flow waves: Surges, stops, flight, and retrenchment. Working Paper 17351, National Bureau of Economics Research.

Gopinath, S. (2011). Approach to Capital Account Management - Shifting contours. Keynote address at the Annual Conference of the Foreign Exchange Dealers' Association of India, Reserve Bank of India.

Gregorio, J. D. (2011). Current challenges to central banking in emerging market economies. Presentation at the International Symposium of the Banque de France: Regulation in the Face of Global Imbalances, Central Bank of Chile. 
Habermeier, K., C. Baba, and A. Kokenyne (2011). The effectiveness of capital controls and prudential policies in managing large inflows. IMF Staff Discussion Note SDN/11/14, International Monetary Fund.

Hutchison, M., G. K. Pasricha, and N. Singh (2012). Effectiveness of capital controls in India: Evidence from the offshore NDF market. IMF Economic Review (Forthcoming).

Inci, A., A. Ariyoshi, J. C. Kriljenko, K. Habermeier, A. Kirilenko, and B. Laurens (2000). Capital controls: Country experiences with their use and liberalization. Occasional Paper 190, International Monetary Fund.

Kaminsky, G. L., C. M. Reinhart, and C. A. Vgh (2005). When it rains, it pours: Procyclical capital flows and macroeconomic policies. In NBER Macroeconomics Annual 2004, Volume 19, NBER Chapters, pp. 11-82.

Kohli, R. (2012). India's experience in navigating the trilemma: Do capital controls help? Working Paper 257, Indian Council for Research on International Economic Relations.

Kokenyne, A. and C. Baba (2011). Effectiveness of capital controls in selected emerging markets in the 2000s. Working Paper 11/281, International Monetary Fund.

Korinek, A. (2011). The New Economics of Capital Controls Imposed for Prudential Reasons. IMF Economic Review (59), 523-561.

Kose, A. M., E. Prasad, and M. Terrones (2009). Does openness to international financial flows raise productivity growth? Journal of International Money and Finance 28(4), 554-580.

Kose, M. A., E. Prasad, K. Rogoff, and S.-J. Wei (2010). Financial globalization and economic policies. In D. Rodrik and M. Rosenzweig (Eds.), Handbook of Development Economics, Volume 5, pp. $4283-4359$.

Lane, P. and G. Milesi-Ferretti (2007). The external wealth of nations mark II: Revised and extended estimates of foreign assets and liabilities, 1970-2004. Journal of International Economics 73(2), 223-250.

Levy Yeyati, E., S. Schmukler, and N. Van Horen (2009). International financial integration through the law of one price: The role of liquidity and capital controls. Journal of Financial Intermediation 18(3), 432-463.

Ma, G., C. Ho, and R. McCauley (2004). The markets for non-deliverable forwards in Asian currencies. BIS Quarterly Review, 81.

Magud, N. E., C. M. Reinhart, and K. S. Rogoff (2011). Capital Controls: Myth and Reality - A Portfolio Balance Approach. Working Paper 16805, National Bureau of Economics Research.

Mistry, P. (2007). Making Mumbai an International Financial Centre. Committee report, Ministry of Finance, Government of India.

Mohan, R. and M. Kapur (2009). Managing the impossible trinity: Volatile capital flows and indian monetary policy. Working Paper 401, Stanford Center for International Development. 
Ostry, J., A. R. Ghosh, K. Habermeier, M. Chamon, M. S. Qureshi, and D. B. Reinhardt (2010). Capital inflows: The role of controls. Staff Position Note SPN/10/04, International Monetary Fund.

Ostry, J. D., A. R. Ghosh, M. Chamon, and M. S. Qureshi (2011, August). Capital Controls: When and Why? IMF Economic Review 59(3), 562-580.

Ostry, J. D., A. R. Ghosh, M. Chamon, and M. S. Qureshi (2012). Tools for managing financialstability risks from capital inflows. Journal of International Economics (Forthcoming).

Patnaik, I. (2005). India's experience with a pegged exchange rate. In S. Bery, B. Bosworth, and A. Panagariya (Eds.), The India Policy Forum 2004, pp. 189-226.

Patnaik, I. (2007, March). India's currency regime and its consequences. Economic and Political Weekly 42(11), 911-913.

Patnaik, I. and A. Shah (2009a). The difficulties of the Chinese and Indian exchange rate regimes. European Journal of Comparative Economics 6(1), 157-173.

Patnaik, I. and A. Shah (2009b). Why India choked when Lehman broke. India Policy Forum 6.

Patnaik, I. and A. Shah (2010). Does the currency regime shape unhedged currency exposure? Journal of International Money and Finance 29, 760-769.

Patnaik, I. and A. Shah (2011). Macroprudential policies and regulatory arbitrage: Lessons from mortgage regulation in India. Presentation at Conference on 'Managing Real Estate Booms and Busts', International Monetary Fund and Bank of Korea.

Patnaik, I., A. Shah, A. Sethy, and V. Balasubramaniam (2011). The exchange rate regime in Asia: From crisis to crisis. International Review of Economics and Finance 20(1), 32-43.

Pradhan, M., R. Balakrishnan, R. Baqir, G. Heenan, S. Nowak, C. Oner, S. Panth, and M. Pradhan (2011). Policy responses to capital flows in emerging markets. Staff Discussion Note SD/11/10, International Monetary Fund.

Prasad, E. (2009). India's approach to capital account liberalization. Discussion Paper 3927, Institute for Study of Labour.

Prasad, E. and R. Rajan (2008). A pragmatic approach to capital account liberalization. Working Paper 14051, National Bureau of Economics Research.

Quinn, D., M. Schindler, and A. M. Toyoda (2011). Assessing measures of financial openness and integration. IMF Economic Review 59(3), 488-522.

Quinn, D. and A. Toyoda (2007). Ideology and voter preferences as determinants of financial globalization. American Journal of Political Science 51(2), 344-363.

Rajan, R. (2008). A hundred small steps. Committee report, Planning Commission, Government of India.

RBI (2004). Monetary policy in an open economy. In R. Mohan (Ed.), Report on Currency and Finance, Volume 1, Chapter 1, pp. 80-111. 
Reddy, Y. (1998). Managing capital flows. Speech at Asia/Pacific Research Centre, Stanford University, Reserve Bank of Inda.

Reddy, Y. (2000). Capital Flows and Self Reliance Redefined. 27th Frank Moraes Memorial Lecture, Reserve Bank of India.

Reddy, Y. (2004). Capital account liberalisation and capital controls. Speech at Central Bank Governors' Symposium, Reserve Bank of India.

Reddy, Y. (2006). Dynamics of Balance of Payments in India. Speech at Diamond Jubilee Celebrations of the Department of Commerce, Osmania University, Reserve Bank of India.

Reinhart, C. and K. Rogoff (2009). This time is different: Eight centuries of financial folly. Princeton Univ Press.

Schindler, M. (2009, April). Measuring financial integration: A new data set. IMF Staff Papers $56(1), 222-238$.

Schneider, M. and A. Tornell (2004). Balance Sheet Effects, Bailout Guarantees and Financial Crises. Review of Economic Studies 71(3), 883-913.

Shah, A. and I. Patnaik (2007). India's experience with capital flows: The elusive quest for a sustainable current account deficit. In S. Edwards (Ed.), Capital controls and capital flows in emerging economies: Policies, practices and consequences, Chapter 13, pp. 609-643.

Shah, A. and I. Patnaik (2011). India. In J. Caprio (Ed.), Encyclopaedia of Financial Globalization, Chapter 67. Elsevier.

Sinha, U. K. (2010). Working group on foreign investment. Committee report, Department of Economic Affairs, Ministry of Finance, Government of India.

Stigler, M., A. Shah, and I. Patnaik (2010, July). Macroeconomic information content of the ADR premium under market segmentation. Working Paper 71, National Institute of Public Finance and Policy.

Warnock, F. (2011). Doubts about capital controls. Working Paper 14, Council on Foreign Relations.

Zeileis, A., A. Shah, and I. Patnaik (2010, June). Testing, monitoring, and dating structural changes in exchange rate regimes. Computational Statistics \& Data Analysis 54(6), 16961706. 